\title{
Isolated metastasis of hepatocellular carcinoma in the right ventricle
}

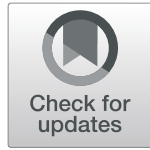

\author{
Xin-tong Zhang ${ }^{1}$, Ying Li ${ }^{1}$, Si-hua Ren ${ }^{2}$, Wei-dong Ren ${ }^{1 *}$ (D), Guang Song ${ }^{1}$, Yang-jie Xiao ${ }^{1}$, Fei-fei Sun ${ }^{1}$, Lu Sun ${ }^{1}$, \\ Xiang-hong Yang ${ }^{1}$ and Xue-ying Tan ${ }^{1}$
}

\begin{abstract}
Background: Hepatocellular carcinoma (HCC) with right ventricle metastasis without inferior vena cava and right atrium involvement is very rare and the prognosis of HCC with RV metastasis is generally poor. The mass in the cardiac chamber may lead to lethal instability of hemodynamics, however, the initial symptom is probably nonspecific, which means that diagnosis timely becomes even harder.

Case presentation: We present a 63-year-old male with isolated metastasis of HCC in the right ventricle which caused inflow obstruction. Moreover, we reviewed a series of studies of isolated metastasis of hepatocellular carcinoma between 1980 and 2018, and summarized the relative outcomes.

Conclusions: Isolated metastasis of hepatocellular carcinoma in the right ventricle is extraordinarily rare. It may damage cardiac structure and broke hemodynamic balance. Multimodality imaging plays an important in accurate pre-operation assessment. Nowadays, palliative treatments could relieve fatal symptoms to some degree, however, standard treatment has not been well established.
\end{abstract}

Keywords: Hepatocellular carcinoma, Metastasis, Echocardiography, Right ventricle, Treatment, Inflow obstruction

\section{Background}

Right heart cavity occlusion secondary to metastatic hepatocellular carcinoma (HCC) with cephalad extension via the inferior vena cava (IVC) is rarely reported. The incidence is less than $6 \%$ in an autopsy series according to literature review [1]. Furthermore, isolated intracavitary metastasis HCC to the right ventricle (RV) without right atrium (RA) and IVC represents rarer events. The prognosis is poor for metastatic HCC, however, surgical treatment may relief their symptoms and improve life quality. Herein, we report a case of isolated metastasis of HCC in RV diagnosed by multimodality cardiac imaging. Meanwhile we review and summarize similar cases from 1980 to 2019 in English literature and related outcomes.

\section{Case presentation}

A 63-year-old male with a reported history of primary HCC treated with surgery and interventional chemotherapy 2 years ago was admitted to our hospital. He suffered

\footnotetext{
* Correspondence: renwd01@163.com

${ }^{1}$ Department of Ultrasound, Shengjing Hospital of China Medical University,

sanhao street 36\#, Liaoning, Shenyang 110004, China

Full list of author information is available at the end of the article
}

from shortness of breath, abdominal distention and palpitation for 1 month. On physical examination, a grade 3/6 systolic murmur over the pulmonary area was heard. Edema in both lower limbs was observed. ECG demonstrated sinus rhythm, ventricular premature contraction and complete right bundle branch block. Laboratory findings showed that his NT-proBNP level was $1769 \mathrm{pg} /$ $\mathrm{ml}$, CKMB was $27 \mathrm{U} / \mathrm{L}$ and TnI was $0.249 \mu \mathrm{g} / \mathrm{ml}$. He had no history of hepatic virus infection. Other findings were albumin33.7 g/L, GGT97U/L, BilT26.4umol/L, Bil$\mathrm{D} 10.7 \mathrm{umol} / \mathrm{L}$, uric444 umol/L and CRP114mg/L.

Positron emission tomography CT (PETCT) in other hospital showed that there was no nodule in the liver but some sporadic nodules in the lung. Large amount of pericardial effusion could also be observed. Transthoracic echocardiography (TTE) revealed a huge mass with moderate echogenicity in right ventricle (RV) which caused severe inflow obstruction. The mass blocked almost the whole cavity and showed little degree of mobility along with the cardiac cycle. The right ventricle outflow tract (RVOT) was also partially occupied, however, the speed of pulmonary artery (PA) remained normal $(1.0 \mathrm{~m} / \mathrm{s})$. Contrast echocardiography (CE) 
demonstrated higher perfusion in the mass than in the myocardium after the administration of contrast agent. Cord-like vascular perfusion was observed in the mass. Color Doppler imaging showed fine and high velocity flow with the speed of $2 \mathrm{~m} / \mathrm{s}$ in RV. Enlarged RV, RA and PA were also noted. Massive pericardial effusion was detected with enlarged IVC.(Fig. 1) Cardiac MRI confirmed that the huge mass had a size of $93 \times 50 \times 81 \mathrm{~mm}$ and appeared lobular, and it seemed to have blurred the outline of anterior and lateral wall of RV.(Fig. 2) As his physical condition deteriorated rapidly, a cardiac surgery was operated to relieve the fatal obstruction. Fortunately, the patient was discharged one week after the surgery because of great improvement in his physical condition.

\section{Discussion and conclusion}

The incidence of secondary tumor metastasis to heart is reported to be $1.5-21 \%$. The metastasic tumors include melanoma which is of the highest incidence, renal cell carcinoma, breast, lung, thyroid and thymic carcinoma [2]. Other metastatic cardiac tumors are lymphomas and various sarcomas. Of patients with HCC, 5-10\% will have cardiac metastasis. We reviewed a series of recent studies of isolated metastasis of HCC in RV between 1980 and 2018 and summarized relative outcomes.

In all 13 patients with the diagnosis of isolated RV metastasis $\mathrm{HCC}$ were identified. A summary of the patients is presented in Table 1 . There were 5 females and 8 males with an age ranging from 43 to 79 years old. The conditions of RV obstruction caused by the mass include inflow (1), inflow and outflow (4), outflow (6) and 2 unknown. Very rarely, patient in our case only had inflow obstruction without outflow obstruction. The history of HCC ranged from 1 year to 10 years, however, it may have less correlation with metastasis to the cardiac chamber. Almost all the cases had myocardial infiltration. It testified the severe damage of myocardium caused by the mass, which may jeopardize cardiac function gradually in a rather silent way without specific symptoms. Treatments for the cardiac mass were mainly surgery and the survival time ranged from death after the surgery to 9 months. Therefore the prognosis remains rather poor and treatments are for relief of symptoms.

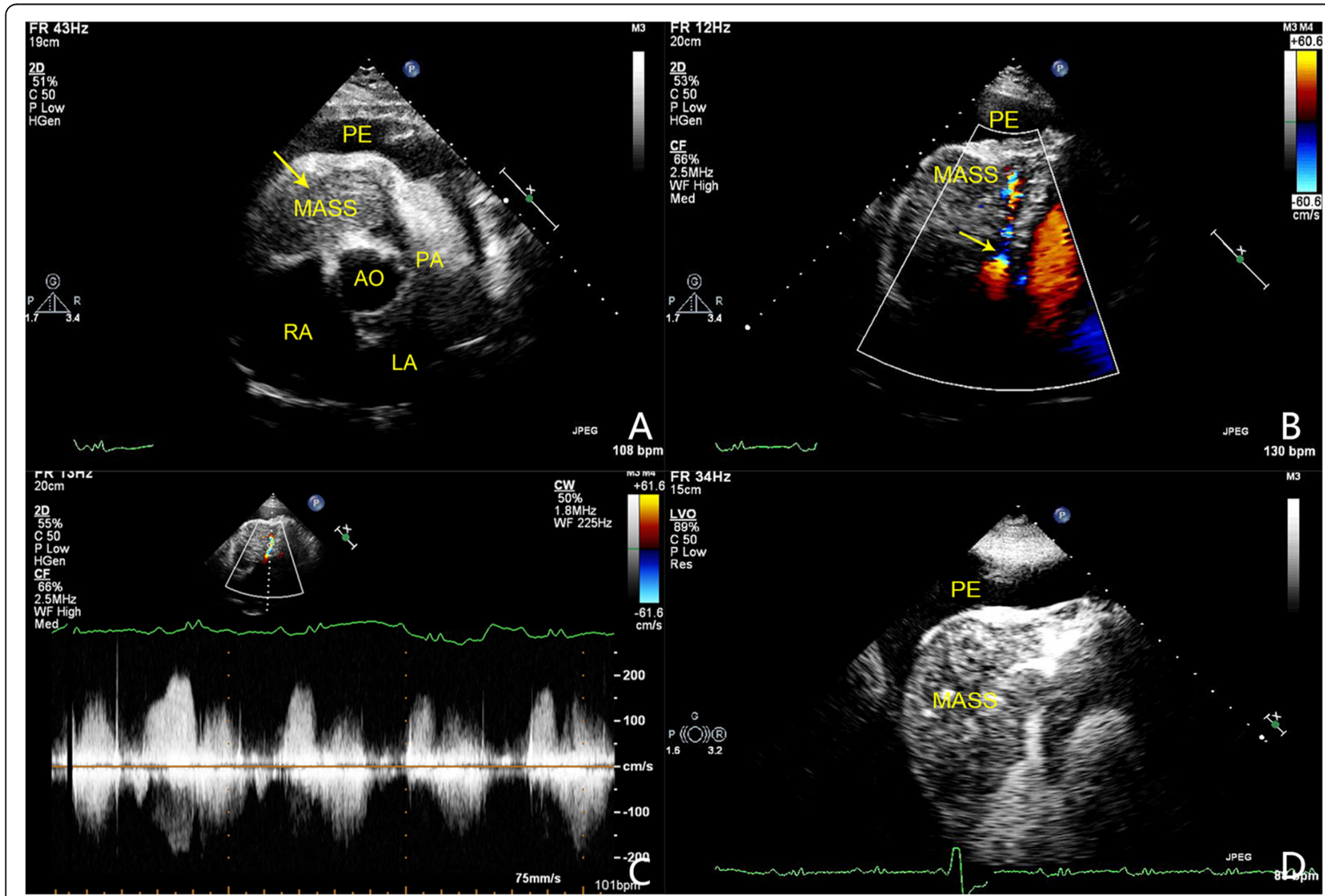

Fig. 1 Echocardiographic findings. A huge mass occupying almost the whole RVOT (yellow arrow). Massive pericardial effusion can be observed. (A); Color Doppler showed fine and high velocity flow in cavity and inflow tract of RV. (B); Continuous-wave Doppler spectrum of the highvelocity flow in the inflow tract of RV, with the peak velocity of $2 \mathrm{~m} / \mathrm{s}$.(C); CE showed higher enhancement of contrast agent in the mass than the myocardium.(D). (AO: aortic artery, CE: contrast echocardiography, LA: left atrium, PA: pulmonary artery, PE:pericardial effusion, RA: right atrium) 


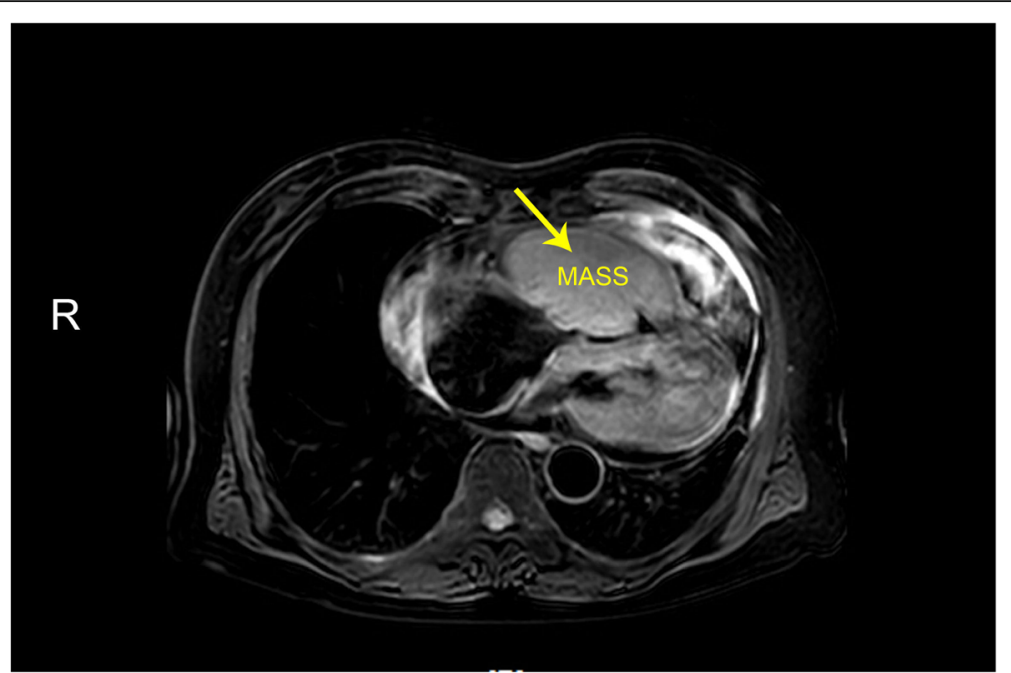

Fig. 2 Cardiac MRI, T2 weighted image showed intracavity RV mass in lobular appearance, with blurred outline with myocardium

Table 1 Summary of patients presenting with HCC with isolated RV metastasis

\begin{tabular}{|c|c|c|c|c|c|c|c|c|c|c|}
\hline Study & Sex & Age & $\begin{array}{l}\text { Size } \\
(\mathrm{mm})\end{array}$ & $\begin{array}{l}\text { RV } \\
\text { Obstruction }\end{array}$ & $\begin{array}{l}\text { Myocardial } \\
\text { infiltraion }\end{array}$ & $\begin{array}{l}\text { Multimodality } \\
\text { imaging }\end{array}$ & $\begin{array}{l}\text { History } \\
\text { of HCC }\end{array}$ & Treatment for HCC & $\begin{array}{l}\text { Treatment for } \\
\text { cardiac mass }\end{array}$ & $\begin{array}{l}\text { Survival } \\
\text { time }\end{array}$ \\
\hline $\begin{array}{l}\text { Steffens et al. } \\
\text { (1980) [3] }\end{array}$ & M & $60 y$ & - & $\begin{array}{l}\text { Inflow, } \\
\text { outflow }\end{array}$ & $(+)$ & $\begin{array}{l}T T E_{1} \\
\text { angiography }\end{array}$ & 6 & Resection & surgery & $\begin{array}{l}\text { Death after } \\
\text { surgery }\end{array}$ \\
\hline $\begin{array}{l}\text { Lei et al. } \\
\text { (1992) [4] }\end{array}$ & M & $54 y$ & - & - & $(+)$ & - & - & - & surgery & 7 months \\
\hline $\begin{array}{l}\text { Kotani } \\
\text { et al.(2000) [5] }\end{array}$ & $\mathrm{F}$ & $67 y$ & $43 \times 37$ & Outflow & $(+)$ & $\begin{array}{l}\mathrm{TTE}, \mathrm{CT} \text {, } \\
\text { angiography }\end{array}$ & 3 & Resection & $\begin{array}{l}\text { transcoronary } \\
\text { chemoembolization }\end{array}$ & Discharge \\
\hline $\begin{array}{l}\text { Longo } \\
\text { et al.(2004) [6] }\end{array}$ & M & $43 y$ & - & - & $(+)$ & X-ray, TTE,CT & 3 & Resection & - & 1 month \\
\hline $\begin{array}{l}\text { Lin et al.(2004) } \\
\text { [7] }\end{array}$ & M & $45 y$ & - & Outflow & - & - & - & chemotherapy & surgery & 3 months \\
\hline $\begin{array}{l}\text { Chieng } \\
\text { et al.(2005) [8] }\end{array}$ & $\mathrm{F}$ & $65 y$ & $70 \times 65$ & Outflow & $(+)$ & $\begin{array}{l}\text { US, CT, } \\
\text { angiogram }\end{array}$ & 1 & Resection & surgery & 3 months \\
\hline $\begin{array}{l}\text { Liu et al.(2006) } \\
\text { [7] }\end{array}$ & $\mathrm{F}$ & $45 y$ & - & - & - & - & - & - & $\begin{array}{l}\text { Surgery, } \\
\text { chemotherapy }\end{array}$ & 4 months \\
\hline $\begin{array}{l}\text { Kan } \\
\text { et al.(2008) [7] }\end{array}$ & $\mathrm{F}$ & $74 y$ & - & $\begin{array}{l}\text { Inflow, } \\
\text { outflow }\end{array}$ & $(+)$ & $\begin{array}{l}\text { TTE, } \\
\text { angiography }\end{array}$ & 2 & chemoembolization & surgery & 4 months \\
\hline $\begin{array}{l}\text { Liu et al.(2010) } \\
\text { [9] }\end{array}$ & $\mathrm{F}$ & $46 y$ & $\begin{array}{l}39.1 \times \\
60.2\end{array}$ & $\begin{array}{l}\text { Inflow, } \\
\text { outflow }\end{array}$ & $(+)$ & TTE, CT & 1.17 & $\begin{array}{l}\text { Resection, } \\
\text { chemoembolization }\end{array}$ & surgery & 4 months \\
\hline $\begin{array}{l}\text { Tameda } \\
\text { et al.(2014) } \\
\text { [10] }\end{array}$ & M & $74 y$ & - & $\begin{array}{l}\text { Inflow, } \\
\text { outflow }\end{array}$ & $(+)$ & $\begin{array}{l}\text { TTE, CT, MRI, } \\
\text { PETCT }\end{array}$ & 4 & $\begin{array}{l}\text { Resection, } \\
\text { chemoembolization }\end{array}$ & No surgery & 9 months \\
\hline $\begin{array}{l}\text { Lee } \\
\text { et al.(2015) [2] }\end{array}$ & M & $73 y$ & - & Outflow & $(+)$ & $\begin{array}{l}\mathrm{TTE}, \mathrm{CT} \text {, } \\
\text { angiography }\end{array}$ & 4 & Resection & surgery & - \\
\hline $\begin{array}{l}\text { Compagnoni } \\
\text { et al.(2015) }\end{array}$ & M & $54 y$ & $37 \times 23$ & Outflow & $(+)$ & TTE, CT, MRI & 1 & Liver transplant & $\begin{array}{l}\text { Surgery, } \\
\text { chemotherapy }\end{array}$ & - \\
\hline $\begin{array}{l}\text { Kim } \\
\text { et al.(2016) [1] }\end{array}$ & M & $79 y$ & $\begin{array}{l}49.7 \times \\
32.2\end{array}$ & Outflow & $(+)$ & $\begin{array}{l}\text { TTE, CT, MRI, } \\
\text { PETCT }\end{array}$ & 10 & Resection & surgery & - \\
\hline Present study & M & $63 y$ & $93 \times 50 \times 81$ & Inflow & $(+)$ & $\begin{array}{l}\text { TTE, CE, MRI, } \\
\text { PETCT }\end{array}$ & 2 & $\begin{array}{l}\text { Resection, } \\
\text { chemoembolization }\end{array}$ & surgery & - \\
\hline
\end{tabular}




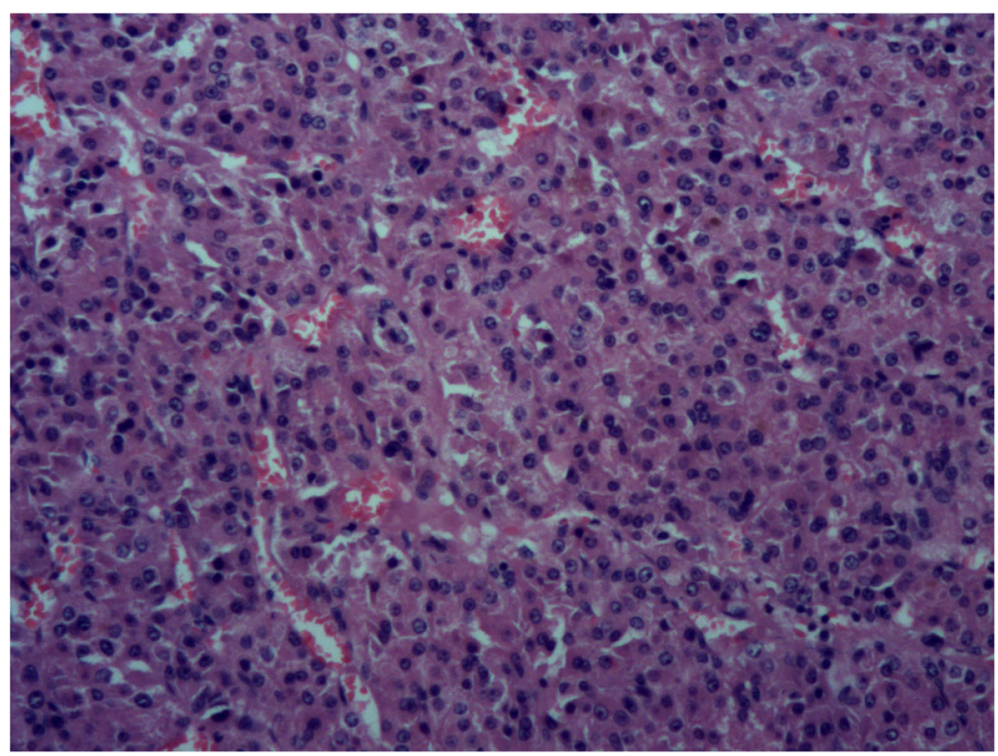

Fig. 3 Histopathological findings of the mass showed tumor cells with markedly enlarged nucleus, pink-stained cytoplasm, gathering in cords or nests with intercellular sinusoids and necrosis (Hematoxylin and Eosin stain $\times 100$ )

In the diagnosis of metastasis HCC to heart, multimodality of cardiac imaging is of vital importance. The diagnosis might be neglected because of non-specific symptoms. According to previous cases, the patients lacked evident symptoms after a segmental hepatectomy or interventional chemotherapy and were found to have a large mass invaded in the cardiac cavities already. Yet, there may be no tumor recurrence in the liver. In our case, PETCT in other hospital didn't provide information about the mass but only pericardial effusion. TTE, as the first means to find the mass, illustrated the contour, nature and mobility of the tumor. The high velocity flow of color Doppler also indicated inflow obstruction in RV. Moreover, higher enhancement of the mass and vascular perfusion in $\mathrm{CE}$ highly suggested malignancy. The huge mass in RV occupying nearly the whole cavity which caused inflow obstruction was confirmed by the surgery. The combination of TTE and CE displayed the mass in a relatively accurate and vivid view. Cardiac MRI provided more detailed information of the mass afterwards, which further confirmed and supported the diagnosis. Based on multimodality cardiac imaging findings, the patient underwent a successful operation of cardiac neoplasm. Surgical findings showed the tricuspid valves were severely blocked and the mass had partially infiltrated into the myocardium. The histopathological findings showed tumor cells growing in distorted version of normal architecture of various sizes. Tumor cells gathered in cords or nests with huge round nucleus, markedly pink-stained cytoplasm. Intercellular sinusoids and necrosis could also be clearly observed. The immunohistochemical findings proved that the mass was hepatocyte-derived and highly malignant.(Fig. 3).
HCC with RV metastasis without IVC and right atrium involvement is exceedingly rare and it may result from hematogenous spread. The prognosis of HCC with RV metastasis is generally poor. Surgical intervention may be palliative treatment to relieve lethal hemodynamic instability, however, the general consensus also believed that the effect of surgery was limited with untreated primary focus [11]. .In our case, chemotherapy was suggested after surgery, but unfortunately the patient refused any further treatment. Besides, transcoronary chemoembolization has also been regarded as a valuable choice. At present, standard treatment has not been well established for metastatic HCC with invasion into the RV [10]. To improve a poor prognosis of metastatic HCC, various approaches combining chemotherapy, radiotherapy, and surgery are needed for both primary and metastatic lesions. These palliative treatments may probably alleviate life-threatening symptoms and prolong survival time to some degree.

\section{Abbreviations}

BilD: Direct bilirubin; BilT: Total bilirubin; CE: Contrast echocardiography; CKMB: Creatine kinase isoenzymes; CRP: $C$ reaction protein; CT: Computed tomography; GGT: Glutamyl transpeptadase; HCC: Hepatocellular carcinoma; IVC: Inferior vena cava; MRI: Magnetic resonance imaging; PA: Pulmonary artery; PETCT: Positron emission tomography CT; RA: Right atrium; RV: Right ventricle; RVOT: Right ventricle outflow tract; Tnl: Troponin I;

TTE: Transthoracic echocardiography; US: Other ultrasonography

\section{Acknowledgements}

We thanked Yue Ma for the MRI image acquisition.

\section{Authors' contributions}

YL performed echocardiographic examination. FFS ensured the accuracy of echocardiographic descriptions. YJX and GS participated in the design of the study and performed data analysis. SHR, LS and XYT analyzed the MRI 
images. XHY revised and modified the pathological descriptions. WDR revised critically for important intellectual content before manuscript submitted. XTZ drafted the manuscript. XTZ and YL shared the same contribution to this article. All authors read and approved the final manuscript.

\section{Funding}

This study was supported by grants from National natural Science Foundation of China (81571686 to W.D.R) and National natural Science Foundation of Liaoning (2018053064 to F.F.S). The funding bodies assisted in the collection of clinical datas and publication fees.

\section{Availability of data and materials}

All data that was generated or analyzed during the current study are available from the corresponding author on reasonable request.

\section{Ethics approval and consent to participate}

The study has been approved by the ethics committee of Shengjing Hospital of China Medical University, Shenyang, China.

\section{Consent for publication}

Written informed consent was obtained from the patient for publication of this case report and any accompanying images.

\section{Competing interests}

The authors declare that they have no competing interests.

\section{Author details}

'Department of Ultrasound, Shengjing Hospital of China Medical University, sanhao street 36\#, Liaoning, Shenyang 110004, China. ${ }^{2}$ Department of Radiology, The First Hospital of China Medical University, najing north street 155\#, Shenyang 110000, China

Received: 3 July 2019 Accepted: 29 November 2019

Published online: 12 December 2019

\section{References}

1. Kim SB, Shin YC, Kwon SU. Isolated metastasis of hepatocellular carcinoma in the right ventricle: a case report. Med (Baltimore). 2016;95(51):e5544.

2. Lee WC, Fu M, Liu WH. Isolated right ventricular infiltrating tumour: metastatic hepatocellular carcinoma. Int J Cardiovasc Imaging. 2015;31(7): 1347-9.

3. Steffens TG, Mayer HS, Das SK. Echocardiographic diagnosis of a right ventricular metastatic tumor. Arch Intern Med. 1980;140(1):122-3.

4. Lei MH, Ko YL, Kuan P, Lien WP, Chen DS. Metastasis of hepatocellular carcinoma to the heart: unusual patterns in three cases with antemortem diagnosis. J Formos Med Assoc = Taiwan yi zhi. 1992;91(4):457-61

5. Kotani E, Kiuchi K, Takayama M, Takano T, Tabata M, Aramaki T, Kawamata H. Effectiveness of transcoronary chemoembolization for metastatic right ventricular tumor derived from hepatocellular carcinoma. Chest. 2000;117(1):287-9.

6. Longo R, Mocini D, Santini M, Giannantoni P, Carillio G, Torino F, Auriti A, Marcello $R$, Lanzi G, Cortese F, et al. Unusual sites of metastatic malignancy: case 1. Cardiac metastasis in hepatocellular carcinoma. J Clin Oncol : Official J Am Soc Clin Oncol. 2004;22(24):5012-4.

7. Kan CB, Chang RY, Chen CK. Isolated right ventricular intracavitary metastasis of hepatocellular carcinoma in a 74-year-old woman. J Chinese Med Assoc : JCMA. 2008;71(6):318-20.

8. Chieng SH, Lin CH, Lu MJ, Hung CR. Intracavitary metastatic hepatocellular carcinoma of the right ventricle. Thorac Cardiovasc Surg. 2005;53(2):123-5.

9. Liu WC, Lui KW, Ho MC, Fan SZ, Chao A. Right ventricular exclusion for hepatocellular carcinoma metastatic to the heart. J Cardiothorac Surg. 2010:5:95.

10. Tameda M, Shiraki K, Takei Y. Isolated metastasis of hepatocellular carcinoma in the right ventricle. Clin Gastroenterol Hepatol : Official Clin Pract J Am Gastroenterol Associ. 2014;12(4):A25-6.

11. Monzio Compagnoni N, Durkovic S, Alamanni F, Zanobini M. Resection of right ventricular metastasis subsequent to liver transplant for hepatocellular carcinoma. J Card Surg. 2015;30(8):656-8.

\section{Publisher's Note}

Springer Nature remains neutral with regard to jurisdictional claims in published maps and institutional affiliations.

Ready to submit your research? Choose BMC and benefit from:

- fast, convenient online submission

- thorough peer review by experienced researchers in your field

- rapid publication on acceptance

- support for research data, including large and complex data types

- gold Open Access which fosters wider collaboration and increased citations

- maximum visibility for your research: over $100 \mathrm{M}$ website views per year

At BMC, research is always in progress.

Learn more biomedcentral.com/submissions 